University of Wollongong

Research Online

Faculty of Engineering and Information

Faculty of Engineering and Information

Sciences - Papers: Part A

Sciences

$1-1-2013$

\title{
Performance monitoring of rail tracks stabilized by geosynthetics and shock mats: case studies at Bulli and Singleton in Australia
}

Buddhima Indraratna

University of Wollongong, indra@uow.edu.au

Sanjay Nimbalkar

University of Wollongong, sanjayn@uow.edu.au

Pongpipat Anantanasakul

University of Wollongong, pongpipa@uow.edu.au

Cholachat Rujikiatkamjorn

University of Wollongong, cholacha@uow.edu.au

Tim Neville

Australian Rail Track Corporation Ltd

Follow this and additional works at: https://ro.uow.edu.au/eispapers

Part of the Engineering Commons, and the Science and Technology Studies Commons

Research Online is the open access institutional repository for the University of Wollongong. For further information contact the UOW Library: research-pubs@uow.edu.au 


\title{
Performance monitoring of rail tracks stabilized by geosynthetics and shock mats: case studies at Bulli and Singleton in Australia
}

\begin{abstract}
Rail tracks are conventionally built on compacted ballast and structural fill embankments overlying the natural subsoil. Ballast plays an important role in providing track stiffness to support heavy traffic loads, and providing rapid drainage. However, ballast deforms and degrades progressively under the heavy cyclic loading of passenger and freight trains, which may lead to a loss of track geometry, and require costly regular maintenance. In particular, track construction requires appropriate stabilization techniques for ballast, the extent of which depends also on the type of subgrade. Comprehensive field trials were carried out on two rail lines in Bulli and recently in Singleton, New South Wales, Australia. In these studies, several track sections were reinforced with different types of geosynthetics placed beneath the ballast embankment. Both fresh and recycled ballast was examined for varying subgrade conditions.

Recoverable and irrecoverable deformations of the substructure were routinely monitored. It was found that geogrids and geocomposites can decrease the vertical strains of the ballast layer, resulting in reduced maintenance costs. This paper describes the comprehensive field instrumentation, construction procedures, and field performance evaluation of these full-scale geosynthetic- stabilized ballast embankments in Bulli and Singleton.
\end{abstract}

\section{Keywords}

case, studies, bulli, singleton, australia, rail, tracks, performance, stabilized, monitoring, geosynthetics, shock, mats

\section{Disciplines}

Engineering | Science and Technology Studies

\section{Publication Details}

Indraratna, B., Nimbalkar, S., Anantanasakul, P., Rujikiatkamjorn, C. \& Neville, T. (2013). Performance monitoring of rail tracks stabilized by geosynthetics and shock mats: case studies at Bulli and Singleton in Australia. Geo-Congress 2013 (pp. 19-33). American Society of Civil Engineers. 


\title{
Performance Monitoring of Rail Tracks Stabilized by Geosynthetics and Shock Mats: Case Studies at Bulli and Singleton in Australia
}

\author{
Buddhima Indraratna, F.ASCE ${ }^{1}$, Sanjay Nimbalkar², Pongpipat Anantanasakul ${ }^{3}$, \\ Cholachat Rujikiatkamjorn ${ }^{4}$, and Tim Neville ${ }^{5}$
}

\begin{abstract}
${ }^{1}$ Professor of Civil Engineering and Research Director, Centre for Geomechanics and Railway Engineering; Program Leader, ARC Centre of Excellence for Geotechnical Science and Engineering; University of Wollongong, Wollongong City, NSW 2522, Australia; PH (+61) 2 4221-3046; FAX (+61) 2 4221-3293; email: indra@uow.edu.au

${ }^{2}$ Research Fellow, Centre for Geomechanics and Railway Engineering; ARC Centre of Excellence for Geotechnical Science and Engineering; University of Wollongong, Wollongong City, NSW 2522, Australia; PH (+61) 2 4221-3385; FAX (+61) 2 4221-3238; email: sanjayn@uow.edu.au

${ }^{3}$ Research Fellow, Centre for Geomechanics and Railway Engineering; CRC for Rail Innovation; University of Wollongong, NSW 2522; PH (+61) 2- 4221-4588; FAX (+61) 2-4221-3238; email: pongpipa@uow.edu.au

${ }^{4}$ Senior Lecturer, Centre for Geomechanics and Railway Engineering; ARC Centre of Excellence for Geotechnical Science and Engineering, University of Wollongong, NSW 2522, Australia; PH (+61) 2 4221-5852; FAX (+61) 2 4221-3238; email: cholacha@uow.edu.au

${ }^{5}$ Senior Geotechnical Engineer, Australian Rail Track Cooperation Ltd., Broadmeadow, NSW 2292, Australia; PH (+61) 2 4941-9665; FAX (+61) 2 4941-9738; email: tneville@artc.com.au
\end{abstract}

\section{ABSTRACT}

Rail tracks are conventionally built on compacted ballast and structural fill embankments overlying the natural subsoil. Ballast plays an important role in providing track stiffness to support heavy traffic loads, and providing rapid drainage. However, ballast deforms and degrades progressively under the heavy cyclic loading of passenger and freight trains, which may lead to a loss of track geometry, and require costly regular maintenance. In particular, track construction requires appropriate stabilization techniques for ballast, the extent of which depends also on the type of subgrade.

Comprehensive field trials were carried out on two rail lines in Bulli and recently in Singleton, New South Wales, Australia. In these studies, several track sections were reinforced with different types of geosynthetics placed beneath the ballast embankment. Both fresh and recycled ballast was examined for varying subgrade conditions. Recoverable and irrecoverable deformations of the substructure were routinely monitored. It was found that geogrids and geocomposites can decrease the vertical strains of the ballast layer, resulting in reduced maintenance costs. This paper describes the comprehensive field instrumentation, construction procedures, and field performance evaluation of these full-scale geosynthetic- stabilized ballast embankments in Bulli and Singleton.

\section{INTRODUCTION}

Ballasted rail tracks are widely used throughout the world. In these conventional type of tracks, a layer of ballast is placed above the sub-ballast or subgrade to act as a load bearing platform to support the track superstructure. The breakage of asperities (sharp corners), repeated grinding and crushing of rock aggregates under high cyclic 
and impact loading, causes differential track settlement that adversely affects track geometry and results in more frequent maintenance. Several previous researchers have highlighted ballast breakage and confining pressure as the key parameters in the design of ballasted rail tracks (Marshal 1973, Indraratna et al. 2005, Lackenby et al. 2007).

The potential use of geosynthetics to improve stability has already been observed in several laboratory studies (Selig and Waters 1994, Raymond 2002, Indraratna and Salim 2003, Indraratna et al. 2007, 2010), but recent laboratory studies by Brown et al. (2007) and Indraratna et al. (2011a) have shown that the effectiveness of geogrid reinforcement is highly dependent on the stiffness and size of the apertures. A 30\% increase in the stiffness of geogrid has resulted in up to $20 \%$ smaller vertical strain on the ballast, while the apertures providing the best interlocking between the geogrids and ballast are between 1.1 and 1.7 times the median particle size $\left(d_{50}\right)$ of the ballast. The magnitude of the impact loads vary depending upon irregularities in the wheels or rails, and the dynamic response of the track (Jenkins et al., 1974; Indraratna et al., 2011b). Installing resilient mats such as rubber pads (shock mats) in rail tracks can substantially attenuate the dynamic impact force (Nimbalkar et al., 2012). However, only a few studies have assessed the relative merits of geosynthetics and shock mats under a track in in-situ conditions, and the 'field' performance of different types of geosynthetics to improve the overall stability of ballasted rail tracks has not been investigated systematically. Therefore, extensive field trials on sections of instrumented railway track at Bulli and Singleton, New South Wales (NSW), Australia have been conducted. This paper discusses details of the instrumentation and monitoring processes, as well as the findings from these unique field studies.

\section{FIELD STUDY AT BULLI}

In order to gain more insight into the stress-strain mechanism of track substructure and the benefits of using geosynthetics in fresh and recycled ballast, a field trial was undertaken on a section of extensively instrumented track at Bulli, NSW (Indraratna et al., 2010). The design specifications for the track were provided by the University of Wollongong and the field trial was sponsored by RailCorp, Sydney.

\subsection{Track Construction}

In order to investigate the stresses induced by trains, including vertical and lateral deformations, and the benefits of using geosynthetics, a field trial was carried out on a section of instrumented track located between two turnouts at Bulli, part of RailCorp's South Coast Track. The total length of the instrumented track section was $60 \mathrm{~m}$, which was divided into four, $15 \mathrm{~m}$ long sections. The layers of ballast and subballast were $300 \mathrm{~mm}$ and $150 \mathrm{~mm}$ thick, respectively. 


\subsection{Material Specifications}

The particle gradation of fresh ballast (sharp angular coarse aggregates of crushed latite basalt) was in accordance with the Technical Specification TS 3402 (RailCorp, Sydney). Recycled ballast was collected from spoil stockpiles of a recycled plant commissioned by RailCorp at Chullora yard near Sydney. The sub-ballast was a mixture of sand and gravel. The particle size distributions of fresh ballast, recycled ballast, and sub-ballast (capping) materials are given in Figure 1a.

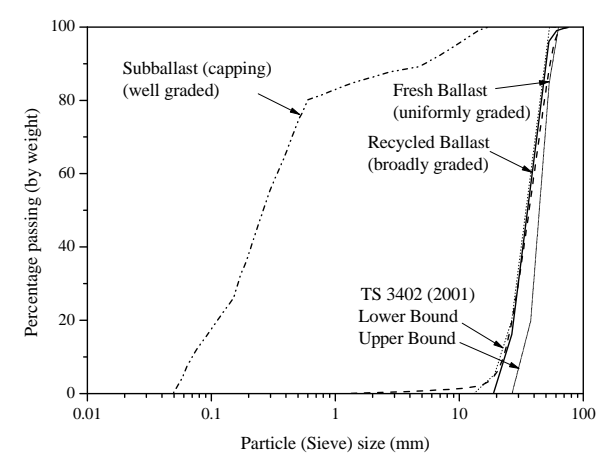

(a)

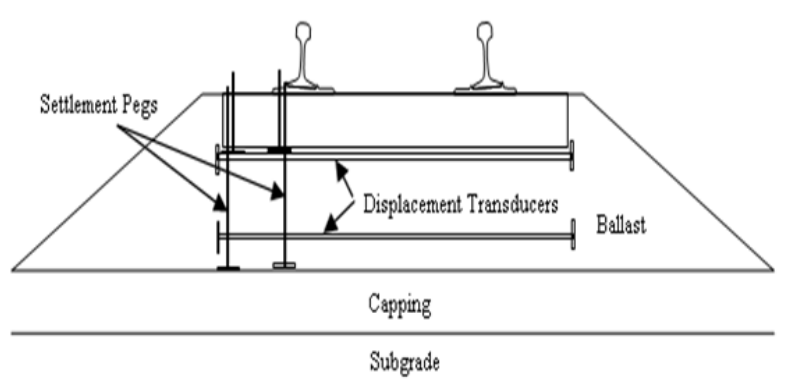

(b)

FIG. 1. (a) Particle size distribution of the ballast and sub-ballast (data sourced from Indraratna et al. 2010); (b) Installation of settlement pegs and displacement transducers in experimental sections of track at Bulli.

Table 1. Grain size characteristics of ballast and sub-ballast (data sourced from Indraratna et al., 2010).

\begin{tabular}{|l|c|c|c|c|c|}
\hline Material & $\begin{array}{l}\boldsymbol{d}_{\max } \\
\mathbf{m m}\end{array}$ & $\begin{array}{c}\boldsymbol{d}_{\min } \\
\mathbf{m m}\end{array}$ & $\begin{array}{c}\boldsymbol{d}_{\mathbf{5 0}} \\
\mathbf{m m}\end{array}$ & $\boldsymbol{C}_{\boldsymbol{u}}$ & $\boldsymbol{C}_{\boldsymbol{c}}$ \\
\hline Fresh Ballast & 75.0 & 19.0 & 35.0 & 1.5 & 1.0 \\
\hline Recycled Ballast & 75.0 & 9.5 & 38.0 & 1.8 & 1.0 \\
\hline Sub-ballast (capping) & 19.0 & 0.05 & 0.26 & 5.0 & 1.2 \\
\hline
\end{tabular}

Table 1 shows the grain size characteristics of the fresh ballast, recycled ballast, and sub-ballast used at the instrumented track at Bulli (Indraratna et al. 2010). The layers of geocomposite consisted of bi-axial geogrids placed over layers of nonwoven polypropylene geotextile. The technical specifications of the geosynthetic material used at this site have already been discussed by Indraratna et al. (2011b).

\subsection{Track Instrumentation}

The performance of the experimental section was monitored using a series of sophisticated instruments. The vertical and horizontal stresses developed in the ballast were measured by rapid response hydraulic earth pressure cells with thick, 
grooved active faces based on semi-conductor type transducers. Vertical and lateral deformations were measured by settlement pegs and electronic displacement transducers, respectively. These transducers were placed inside two, $2.5 \mathrm{~m}$ long stainless steel tubes that can slide over each other, with $100 \mathrm{~mm} \times 100 \mathrm{~mm}$ end caps as anchors. The settlement pegs consisted of $100 \mathrm{~mm} \times 100 \mathrm{~mm} \times 6 \mathrm{~mm}$ stainless steel base plates attached to $10 \mathrm{~mm}$ diameter steel rods. The settlement pegs and displacement transducers were installed between the sleeper and ballast, and between the ballast and sub-ballast, respectively, as shown in Figure 1b.

\subsection{Track Measurements}

Vertical and horizontal deformations were measured in the field, against time. A relationship between the annual rail traffic in million gross tons (MGT) and axle load $\left(A_{t}\right)$ was used to determine the number of load cycles (Selig and Waters, 1994):

$$
\mathrm{C}_{\mathrm{m}}=\frac{10^{6}}{\left(\mathrm{~A}_{\mathrm{t}} \times \mathrm{N}_{\mathrm{a}}\right)}
$$

where $C_{m}=$ number of load cycles/MGT; $A_{t}=$ axle load in tons; and $N_{a}=$ number of axles/load cycle. Considering an annual tonnage of $60 \mathrm{MGT}$ of traffic, and four axles per load cycle, an axle load of 25 tons gives 600,000 load cycles per year for 60 MGTpa track. Therefore the results were plotted against the time and number of load cycles, as discussed below.

\subsubsection{Traffic induced peak stresses in ballast}

Figure 2a shows the maximum vertical cyclic stresses $\left(\sigma_{v}\right)$ and maximum horizontal cyclic stresses $\left(\sigma_{h}\right)$ recorded in Section 1 , under the rail and the edge of the sleeper, from a passenger train travelling at $60 \mathrm{~km} / \mathrm{h}$ (20.5 ton axle load). Under a normal rail track, there are significant lateral movements in the ballast. The large vertical stresses and relatively small lateral (confining) stresses caused large shear strains in the track. The corresponding ease of lateral spreading due to the absence of sufficient confinement increased the vertical compression of the ballast layer, as was also confirmed by Selig and Waters (1994). Also, $\sigma_{v}$ and $\sigma_{h}$ increased with an increase in the number of load cycles, which further degraded the track bed.

Figure 2b shows the maximum cyclic stresses $\left(\sigma_{v}, \sigma_{h}\right)$ recorded in Section 1 due to the passage of a coal train with 100 ton wagons ( 25 ton axle load), where the stresses were measured under the rail and at the edge of the sleepers. As expected, the maximum cyclic stresses $\left(\sigma_{v}, \sigma_{h}\right)$ measured in the layer of ballast and sub-ballast were higher for a coal freight train than a passenger train. It was shown that the greater axle load of the coal train imposed a higher $\sigma_{v}$ and $\sigma_{h}$ which resulted in a greater deformation and degradation of the ballast, implying the need for earlier track maintenance. 


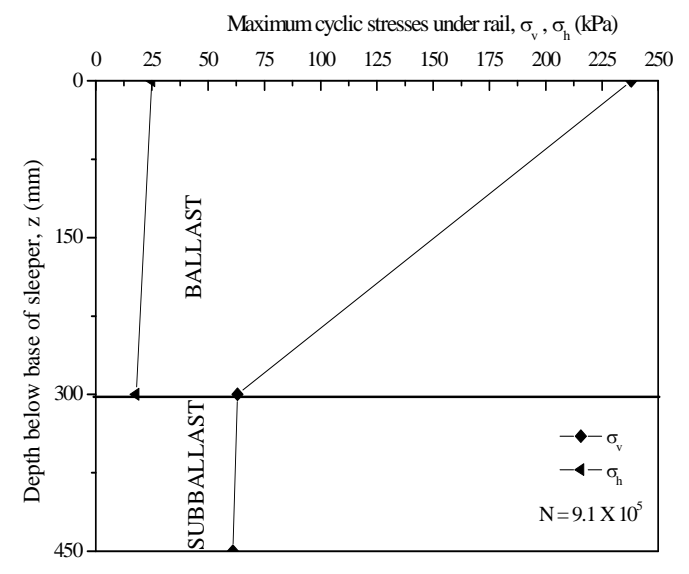

(a)

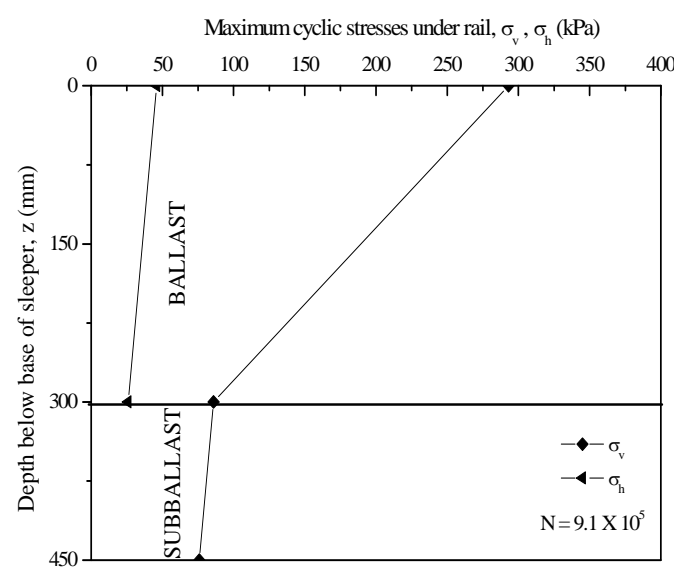

(b)

FIG. 2. Vertical and horizontal maximum cyclic stresses measured under the rails $\left(\sigma_{v}, \sigma_{h}\right)$ for (a) passenger train with 82 class locomotive (82 tons), (b) a coal train with wagons (100 tons) (data sourced from Indraratna et al. 2010)

\subsubsection{Vertical and lateral deformation}

The average vertical and lateral deformations were determined from the mean of measurements between the sleeper and ballast, and between the ballast and subballast. The average vertical and lateral deformations are plotted against the time scale (days) and number of load cycles $(N)$ in Figures 3a and 3b, respectively. The recycled ballast showed improved performances, i.e. less vertical and lateral deformations, because of its moderately graded particle size distribution compared to the very uniform fresh ballast.

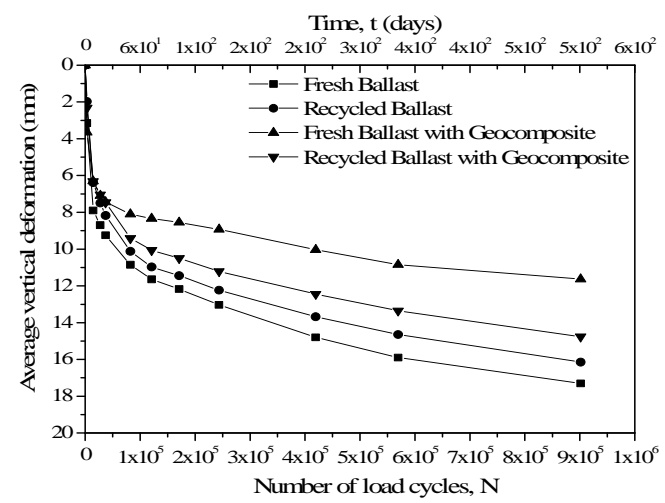

(a)

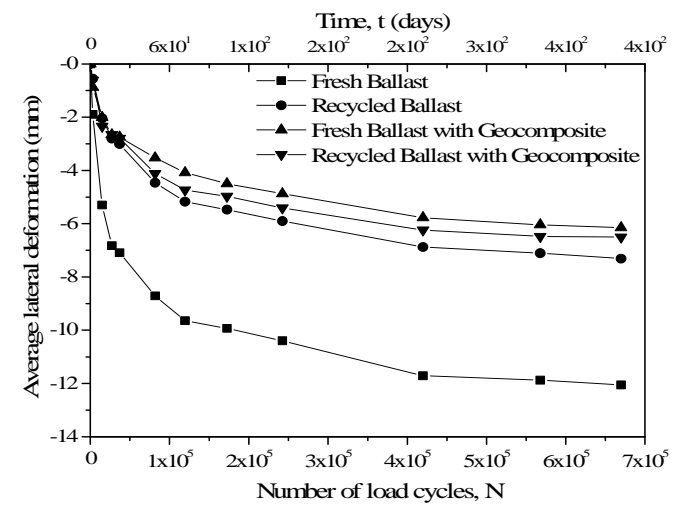

(b)

FIG. 3. Average deformations of the ballast (a) vertical, (b) lateral (data sourced from Indraratna et al., 2010). 
If a layer of ballast is placed with a moderately graded grain size distribution, the corners of individual particles may not break so frequently because of their reduced angularity (less sharp corners/projections). The results of the field trials demonstrated the potential benefits of using a geocomposite at the base of the ballast layer in rail track, where it was able to reduce the vertical deformation of fresh ballast by 33\% and recycled ballast by $9 \%$. It also reduced the lateral deformation of fresh ballast by about $49 \%$ and recycled ballast by $11 \%$. The apertures of the geocomposite offered a strong mechanical interlock with the ballast, forming a highly frictional interface. The ability of geosynthetics to reduce the rate of track deterioration is appealing to the railway industry because the cost of installation is low relative to the substantial financial benefits generated by an extended life span, and more resilient behaviour by the ballast.

\section{FIELD STUDY AT SINGLETON}

\subsection{Track Construction}

The sections of experimental track in this recent study were part of the Third (Relief) Track of the Minimbah Bank Stage 1 Line that extends from Bedford (chainage $224.20 \mathrm{~km})$ to Singleton $(235.06 \mathrm{~km})$, New South Wales. Construction of the Third Track was started in July 2009 and the track was commissioned in May 2010. The Third Track was constructed to decrease the frequent traffic headway and harmonise this section of track with the remainder of the network. The Minimbah Bank Stage 1 Line is owned and operated by the Australian Rail Track Corporation (ARTC), and is mainly used to transport coal from mines in the Hunter Valley to the Port of Newcastle. The line also supports NSW Railcorp's light passenger trains servicing between Maitland and Scone. An extensive program of sub-surface exploration, consisting of 33 bore holes and 107 test pits, indicated that the Third Track was located on a massive sedimentary outcrop of rock, between 224.20 to $229.00 \mathrm{~km}$, and later on the flood plain of the nearby Hunter River (RCA Australia 2008). The rock outcrop was part of the Branxton Formation and mainly composed of medium to high strength siltstone. The flood plain consisted of a layer of an alluvial deposit of silty clay 7-10 m thick, underlain by heterogeneous layers of medium dense sand and silty clay with a total thickness of 7-9 m. Medium strength siltstone, similar to the first part of track, was found beneath the layer of sand and silty clay.

To investigate how well different types of geosynthetics would improve the overall stability of the track under in situ conditions, an extensive study was undertaken on fully instrumented sections of track. Nine experimental sections were included in the Third Track while it was under construction, on three different types of sub-grades, including (i) the relatively soft general fill and alluvial silty clay deposit (Sections 15 and Section A), (ii) the intermediate cut siltstone (Sections 6 and C), and (iii) the stiff reinforced concrete bridge deck supported by a piled abutment (Section B), as shown in Figure 4. 


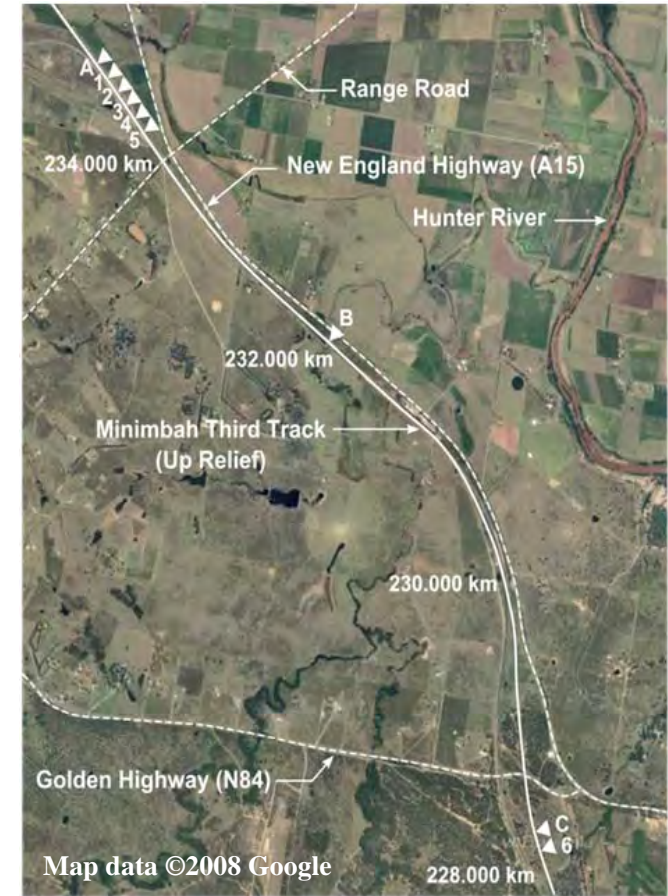

FIG. 4. Locations of experimental sections on three parts of Minimbah Third Track with different values of subgrade stiffness (data sourced from RCA Australia 2008).

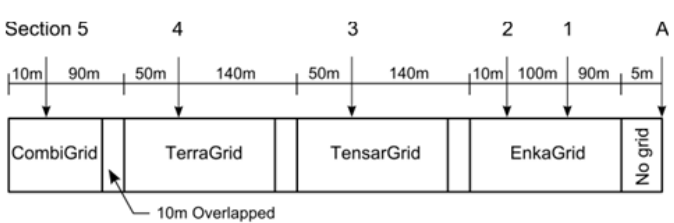

(a)

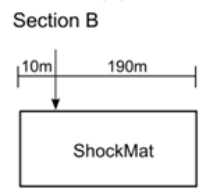

(b)

Section 6

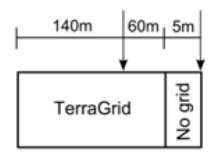

(c)

FIG. 5. Reinforcement of track substructure with different types of synthetic materials.

\subsection{Material Specifications}

The substructure of the track consisted of a $300 \mathrm{~mm}$ thick layer of ballast $\mathrm{r}\left(D_{50}=\right.$ $36 \mathrm{~mm}$, angular latite basalt fragments) underlain by a $150 \mathrm{~mm}$ thick layer of subballast (GP-GM, compacted sandy gravel, CBR $\geq 50 \%, d_{50}=4 \mathrm{~mm}$ ). A structural layer of fill with a minimum of $500 \mathrm{~mm}$ thickness (GP-GM, compacted sandy gravel, CBR $\geq 30 \%, d_{50}=3 \mathrm{~mm}$ ) was placed below the sub-ballast. The gradation and classification (at the time of commission) of the materials used to construct these components are reported in Table 2.

Table 2. Gradation characteristics and USCS classification of ballast, subballast, and structural fill.

\begin{tabular}{|l|l|c|c|c|}
\hline Material & \multicolumn{1}{|c|}{ Description } & $\begin{array}{c}\boldsymbol{d}_{\mathbf{5 0}} \\
(\mathbf{m m})\end{array}$ & $\begin{array}{c}\text { USCS } \\
\text { classification }\end{array}$ & $\begin{array}{c}\boldsymbol{C B R} \\
\mathbf{( \% )}\end{array}$ \\
\hline Ballast & Compacted angular latite basalt & 36 & GP & - \\
\hline Sub-ballast & Compacted sandy gravel & 4 & GP-GM & 50 \\
\hline $\begin{array}{l}\text { Structural } \\
\text { fill }\end{array}$ & Compacted sandy gravel & 3 & GP-GM & 30 \\
\hline
\end{tabular}


Although these materials had different particle gradations, they were all obtained from the same quarry (20 km northwest of Singleton) and were composed of similar minerals. Three commercially available geogrids, namely EnkaGrid, TensarGrid, TerraGrid, and one geocomposite i.e. CombiGrid (geocomposite) were installed in a single layer at the ballast-sub-ballast interface (Figures 5a and 5c) to investigate the key influential factors, i.e., the stiffness, aperture size, and filtration ability under 'field' conditions. The properties of the geosynthetics used in this study are listed in Table 3. The properties reported in the table are in the 'machine' direction followed by those in the 'cross-machine' direction. For comparison purposes, no geosynthetic was installed at Sections A and C. A layer of shock mat was installed between the ballast and bridge deck at Section B (Figure 5b) to minimise any degradation of the ballast. The relevant properties of the shock mat are listed in Table 3.

Table 3. Mechanical properties of (a) geogrids and geocomposite and (b) synthetic mat.

\begin{tabular}{|c|c|c|c|c|c|}
\hline (a) & $\begin{array}{c}\text { Terra } \\
\text { Grid }\end{array}$ & $\begin{array}{c}\text { Tensar } \\
\text { Grid }\end{array}$ & $\begin{array}{c}\text { Enka } \\
\text { Grid }\end{array}$ & \multicolumn{2}{c|}{ CombiGrid } \\
\hline Material & \multicolumn{3}{|c|}{ Polypropylene } & $\begin{array}{c}\text { Poly } \\
\text { propylene } \\
\text { (grid) }\end{array}$ & $\begin{array}{c}\text { Poly } \\
\text { propylene } \\
\text { (fabric) }\end{array}$ \\
\hline Type & biaxial & biaxial & biaxial & biaxial & Nonwoven \\
\hline $\begin{array}{c}\text { Tensile } \\
\text { strength } \\
\text { (kN/m) }\end{array}$ & $30 / 30$ & $30 / 30$ & $36 / 36$ & $40 / 40$ & $6 / 10$ \\
\hline $\begin{array}{c}\text { Strain at } \\
\text { break (\%) }\end{array}$ & $15 / 15$ & $15 / 15$ & $15 / 15$ & $15 / 15$ & $60 / 40$ \\
\hline $\begin{array}{c}\text { Aperture } \\
\text { size (mm) }\end{array}$ & $40 / 40$ & $65 / 65$ & $44 / 44$ & $31 / 31$ & - \\
\hline $\begin{array}{c}\text { Thickness } \\
\text { (mm) }\end{array}$ & 4 & 3 & 3 & 3 & 2.9 \\
\hline
\end{tabular}

\begin{tabular}{|c|c|}
\hline (b) & Shock mat \\
\hline Material & $\begin{array}{c}\text { Polyurethane } \\
\text { elastomer }\end{array}$ \\
\hline Type & $\begin{array}{c}\text { bonded rubber } \\
\text { granulates }\end{array}$ \\
\hline $\begin{array}{c}\text { Particle } \\
\text { size (mm) }\end{array}$ & $1-3$ \\
\hline $\begin{array}{c}\text { Tensile } \\
\text { strength } \\
\text { (kN/m } \text { }^{2}\end{array}$ & 600 \\
\hline $\begin{array}{c}\text { Strain at } \\
\text { break (\%) }\end{array}$ & 80 \\
\hline $\begin{array}{c}\text { Thickness } \\
(\mathrm{mm})\end{array}$ & 10 \\
\hline
\end{tabular}

\subsection{Track Instrumentation}

Figure 6 shows how the instruments were installed at the experimental sections of track to study its behavior under repetitive traffic loads. Strain gauges were used to study deformations and mobilised forces along the layers of geogrid (Figure 6a). Traffic induced vertical stresses were monitored by pressure cells. Transient deformations of the ballast were measured by five potentiometers (POTs) mounted on a custom built aluminum frame, as shown in Figure 6c. Settlement pegs were installed between the sleeper and ballast and between the ballast and sub-ballast to measure vertical deformations of the ballast (Figure 6d). The strain gauges were a post yield type suitable to measure tensile strains between 0.1 to $15 \%$. They were installed in a group, about $200 \mathrm{~mm}$ apart, on the top and bottom sides of the grids, in both the longitudinal and transverse directions (Fig. 6a). At each section, one group of strain gauges was installed below the edge of the sleeper, while another was below the up rail. Protective layers made of vulcanized rubber were used to cover the strain gauges to minimise any damage caused by contact with the ballast. Flexible 
aluminum sleeves were also used to protect the data cables of the strain gauges, as shown in Figure 7.

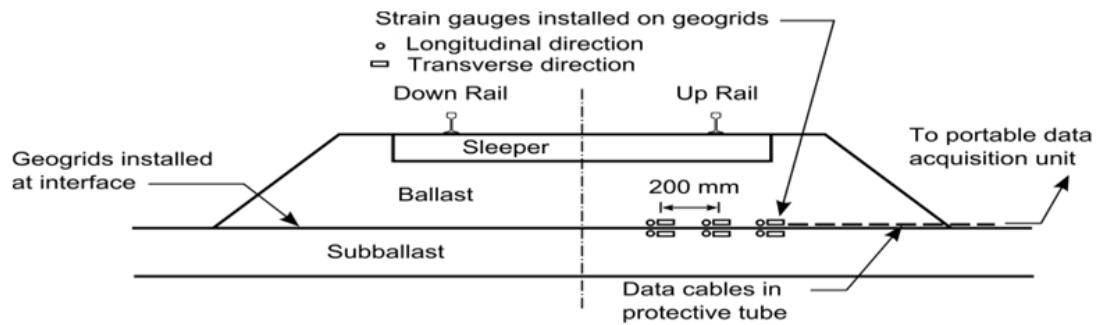

(a)

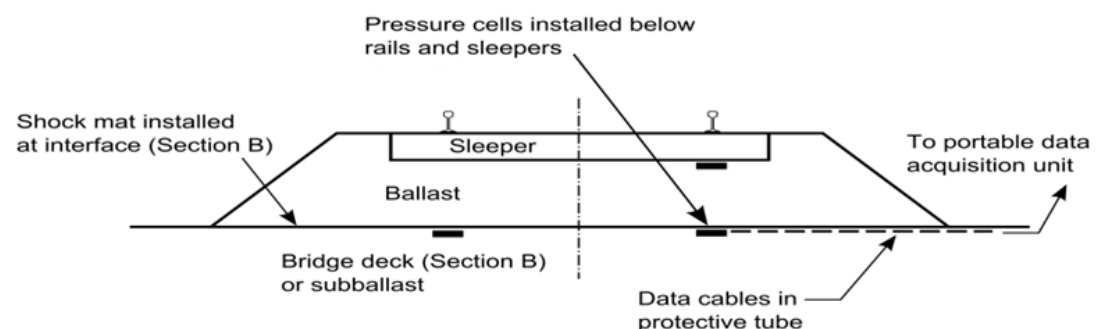

(b)

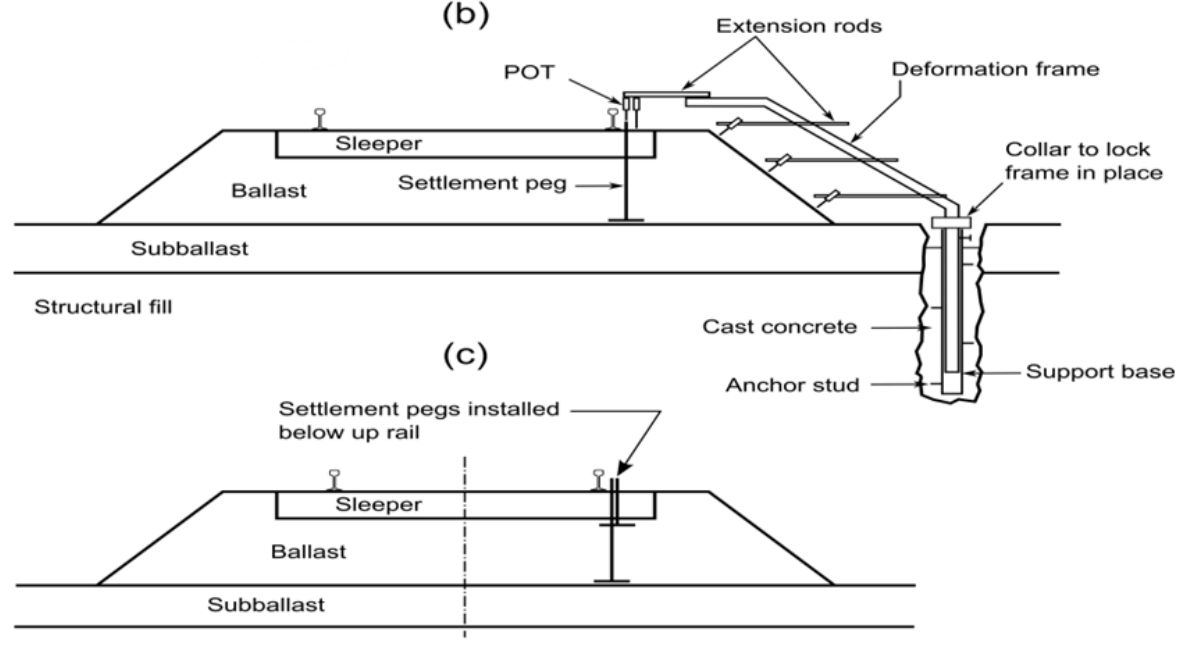

(d)

FIG. 6. Details of instrumentation of experimental sections of track at Singleton using, (a) strain gauges, (b) pressure cells, (c) deformation frame and (d) settlement pegs.

Two pressure cells were installed at Sections 1, 6, A, and C, one directly below the ties and the other directly above the layer of sub-ballast (Fig. 6b). To install them, the ballast was removed and the sub-ballast was levelled. The cells were then placed in position and the ballast backfilled, as shown in Fig. 8. At Section B, three pressure cells were installed between the synthetic mat and the deck. Two cells were located below the up rail, while the other was below the down rail. The two POTs were mounted vertically on the frame (Fig. 6c), one to monitor movement of the sleepers, 
and the other to measure the movement of settlement peg placed at top of the subballast. The other three POTs were mounted in an inclined fashion to monitor the vertical and horizontal deformations of the shoulder of the ballast at different locations. The deformation frame was held in place by support bases installed in the sub-ballast and layers of structural fill. Fig. 9 shows the deformation frame mounted in place to obtain any transient deformation of the ballast at Section A. Transient deformations were monitored at all the experimental sections, except for Section B.

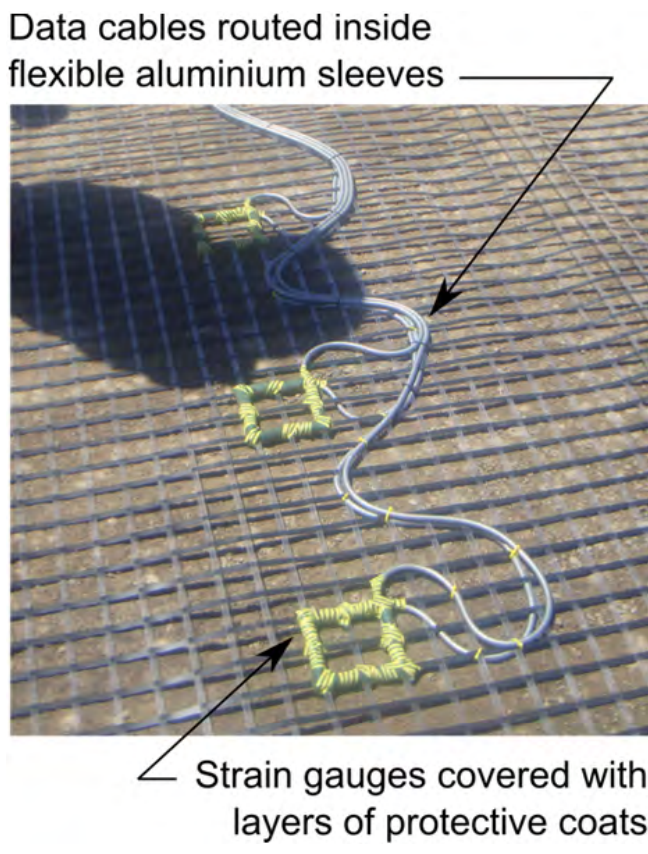

FIG. 7. Strain gauges are covered with several layers of protective coats. Data cables are routed in protective aluminum sleeves to avoid cuts from ballast particles.

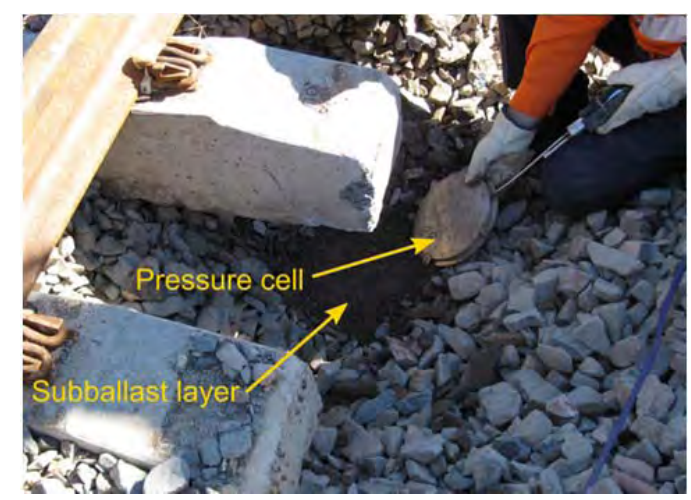

\section{FIG. 8. Installation of pressure cells involves removing and backfilling the ballast.}

Electrical analogue signals from the strain gauges, pressure cells, and potentiometers were obtained using a mobile data acquisition (DAQ) unit shown in Figure 10. The unit consisted of a National Instrument model 9188 module working in parallel with a mobile personal computer. The data acquisition module and associated wiring was housed in a custom made, aluminum case. The module provided electrical excitations and received signals from the instruments. The input signals were amplified and filtered to reduce signal noises. These 'conditioned' signals were converted into a digital format and then later in real time in the mobile computer. The data acquisition module was configured and controlled by a computer program written in the National Instrument's LabView environment. All the field data were obtained from the aforementioned instruments at a frequency of 2,000 $\mathrm{Hz}$. A $12 \mathrm{~V}$ automotive battery provided a direct current power supply to the data 
acquisition module. Alternating power for the mobile computer was also provided by the same battery, but via an inverter.

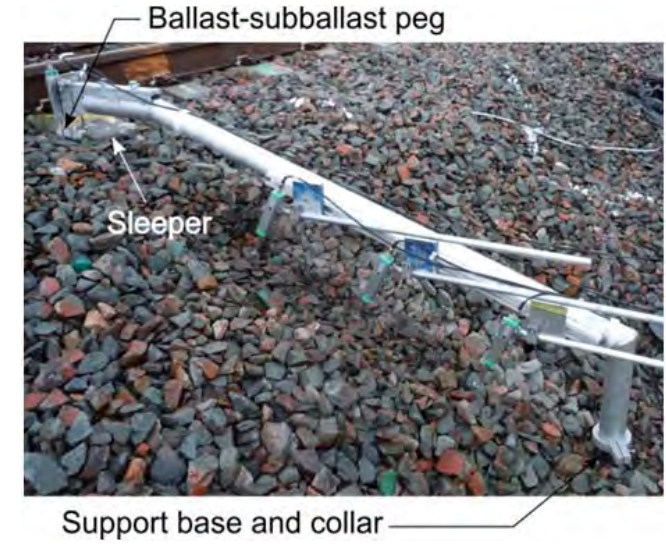

FIG. 9. Displacement monitoring frame mounted on support base.

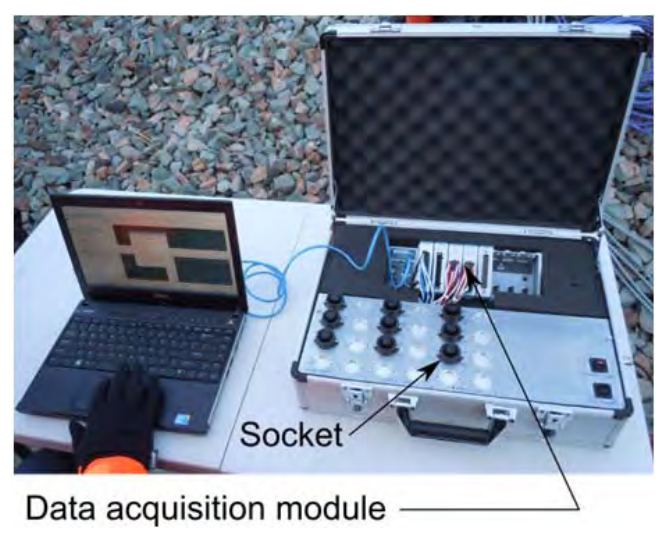

FIG. 10. DAQ module connected to mobile personal computer.

\subsection{Track Measurements}

\subsubsection{Long-term Settlement of Ballast Layer}

The settlement $\left(S_{v}\right)$ and vertical strain $\left(\varepsilon_{v}\right)$ of the ballast after about 100,000 load cycles, or 40 days after the track was commissioned, and about 300,000 load cycles or 120 days, are reported in Table 4. These preliminary results indicate that the relationship between the settlement of ballast and the number of load cycles $(N)$ is non-linear, regardless of how the track was reinforced. The rate at which settlements increased, decreased as the number of load cycles increased. When the results for sections on similar subgrades were compared to each other, vertical settlements of the reinforced sections were $10-32 \%$ smaller than those without reinforcement. This pattern is similar to that observed in the laboratory (Shin et al. 2002 and Brown et al. 2007), and is mainly attributed to the interlocking between ballast particles and grids, as discussed earlier.

When the results for sections with similar geogrids are compared, it is apparent that the ability of geogrid reinforcement to reduce track settlement is generally higher for softer subgrades (low track substructure stiffness). Such an observation is in agreement with the results of the full scale laboratory tests presented by Ashmawy and Bourdeau (1995). Moreover, of the four types of synthetics used, TerraGrid performed most effectively. Although the stiffness of TerraGrid is equal to or lower than the others, its aperture size $(40 \mathrm{~mm})$ enabled better interlocking between the ballast particles and grids. This finding also agrees with the criteria for optimum size apertures for geogrids proposed by Brown et al. (2007) and Indraratna et al. (2011a). When Sections A, B, and C are compared, the results indicate that the vertical 
settlements are larger when the subgrade becomes weaker (low track stiffness), i.e., vertical settlement was smaller at the section on the concrete bridge deck (B) and larger than the section on the alluvial deposit (A).

Table 4. Vertical settlement and strain of the ballast layer after (a) 100,000 load cycles and (b) 300,000 load cycles.

\begin{tabular}{|c|c|c|c|c|c|c|c|c|c|}
\hline Section & $\mathbf{1}$ & $\mathbf{2}$ & $\mathbf{3}$ & $\mathbf{4}$ & $\mathbf{5}$ & $\mathbf{6}$ & $\mathbf{A}$ & $\mathbf{B}$ & $\mathbf{C}$ \\
\hline$S_{v}$ & 15.0 & 19.5 & 17.0 & 10.8 & 14.0 & 13.1 & 20.5 & 5.2 & 14.3 \\
\hline$\varepsilon_{v}(\%)$ & 5.0 & 6.5 & 5.7 & 3.6 & 4.7 & 4.4 & 6.8 & 1.7 & 4.8 \\
\hline Section & $\mathbf{1}$ & $\mathbf{2}$ & $\mathbf{3}$ & $\mathbf{4}$ & $\mathbf{5}$ & $\mathbf{6}$ & $\mathbf{A}$ & $\mathbf{B}$ & $\mathbf{C}$ \\
\hline$S_{v}$ & 19.1 & 23.0 & 21.0 & 4.9 & 17.0 & 17.5 & 24.1 & 8.0 & 18.5 \\
\hline$\varepsilon_{v}(\%)$ & 6.4 & 7.7 & 7.0 & 5.0 & 5.7 & 5.8 & 8.0 & 2.7 & 6.2 \\
\hline
\end{tabular}

(b)

\subsubsection{Transient Deformations of Ballast Layers}

Transient deformations of the ballast layer were measured by the deformation frame. It was observed that the passage of trains with an axial load of 30 tons travelling at $40 \mathrm{~km} / \mathrm{h}$ resulted in a vertical deformation $\left(S_{t v}\right)$ between 1.5 to $3.0 \mathrm{~mm}$, resulting in average vertical strain $\left(\varepsilon_{t v}\right)$ of between 0.5 and $1.0 \%$. The transient horizontal deformations of ballast $\left(S_{t h}\right)$ measured on the shoulder (up rail side) were all expansive and between -0.5 to $-0.3 \mathrm{~mm}$. This resulted in an average horizontal strain $\left(\varepsilon_{t h}\right)$ of -0.05 to $-0.02 \%$. The horizontal strains were larger near the crest and smaller near the toe of ballast. The average transient strains of track sections with reinforcement were about $15 \%$ smaller than those without reinforcement.

\subsubsection{Traffic induced Vertical Stresses in Track}

The vertical stresses $\left(\sigma_{v}\right)$ due to the passage of trains with an axle load of 30 tons travelling at about $40 \mathrm{~km} / \mathrm{h}$ were about $280 \mathrm{kPa}$ at Section B (mat-deck interface) and between 30 to $40 \mathrm{kPa}$ at Sections 1, 6, A, and C (ballast-sub-ballast interface). Vertical stresses at the sleeper-ballast interface of the latter sections were between 170 to $190 \mathrm{kPa}$, which indicate that the traffic-induced stresses were considerably larger in the track with a stiffer subgrade. The larger stresses also caused much more breakage of individual particles of ballast, as was anticipated. The ballast breakage index ( $B B I)$ after 750,000 load cycles (300 days after the track was commissioned) for Sections B was 17\%, while Sections A and C were 9.8\% and 13.1\%, respectively. This finding appears to contradict the general perception that ballast subjected to higher stresses (Section B) would undergo larger settlements and vertical strains due to larger degrees of particle breakage (Lackenby et al. 2007). This is because the ballast at Section B was contained within the barriers of the Mudies Creek bridge, 
which meant that the ballast could not spread laterally. At Sections A and C however, the ballast was allowed to expand more freely in a horizontal direction, and larger vertical settlement was thus observed. This observation also confirms that the ability of ballast to expand horizontally also influences the magnitude of track settlement as well as the degree of ballast breakage.

\subsubsection{Strains in Geosynthetics}

Accumulated longitudinal $\left(\varepsilon_{l}\right)$ and transverse $\left(\varepsilon_{t}\right)$ strains after 100,000 and 300,000 load cycles, as measured by the bottom strain gauges installed below the edges of sleepers, are given in Table 5 . Here, most of permanent strains in the geogrids in both directions developed when the track was being constructed, particularly when the ballast was being placed. In general, the strains did not change very much with the number of load cycles. As shown in Table 5, the transverse strains were generally larger than the longitudinal strains, probably due to confinement or a higher level of longitudinal restraint relative to the transverse direction. The values of $\varepsilon_{l}$ and $\varepsilon_{t}$ also appear to be mainly influenced by deformation of the subgrade. As also shown in the table, the transverse strains developed in the CombiGrid (Section 5) were relatively large, although being stiffer they could have been expected to result in smaller strains because the embankment was constructed from alluvial silty clay and siltstone cuttings, and at this location underwent large lateral deformation shortly after the track was commissioned, which resulted in excessive transverse strains in the geocomposite.

Table 5. Typical values of accumulated longitudinal and transverse strains in geogrids after (a) 100,000 cycles and (b) 300,000 load cycles.

\begin{tabular}{|c|c|c|c|c|c|c|}
\hline Section & $\mathbf{1}$ & $\mathbf{2}$ & $\mathbf{3}$ & $\mathbf{4}$ & $\mathbf{5}$ & $\mathbf{6}$ \\
\hline$\varepsilon_{l}(\%)$ & 0.8 & 0.7 & 0.9 & 0.6 & 0.4 & 0.6 \\
\hline$\varepsilon_{t}(\%)$ & 0.9 & 1.6 & 0.8 & 0.8 & 1.4 & 0.8 \\
\hline
\end{tabular}

(a)

\begin{tabular}{|c|c|c|c|c|c|c|}
\hline Section & $\mathbf{1}$ & $\mathbf{2}$ & $\mathbf{3}$ & $\mathbf{4}$ & $\mathbf{5}$ & $\mathbf{6}$ \\
\hline$\varepsilon_{l}(\%)$ & 0.8 & 0.7 & 1.0 & 0.7 & 0.4 & 0.7 \\
\hline$\varepsilon_{t}(\%)$ & 1.0 & 1.6 & 1.0 & 0.9 & 1.9 & 0.8 \\
\hline
\end{tabular}

(b)

Induced transient strains in both the longitudinal $\left(\Delta \varepsilon_{l t}\right)$ and transverse $\left(\Delta \varepsilon_{t t}\right)$ directions due to the passage of trains with an axial load of 30 tons travelling at 40 $\mathrm{km} / \mathrm{h}$ were between $0.14-0.17 \%$. Unlike the accumulated strains, the values of $\Delta \varepsilon_{\text {lt }}$ and $\Delta \varepsilon_{t t}$ were smaller in grids with higher values of stiffness, but the transient strains in the geogrids were very consistent, and therefore were independent of the number of load cycles. 


\section{CONCLUSIONS}

A comprehensive field monitoring program was undertaken at Bulli and Singleton in NSW, Australia, to study the ability of various geosynthetics to improve the overall stability of ballasted rail tracks. The sophisticated track instrumentation scheme used during field monitoring has led to a significant understanding of the stress-transfer and strain accumulation mechanisms in the track. The results of the Bulli study indicated that the use of geocomposite as reinforcing elements for recycled ballasted tracks proved to be a feasible and effective alternative. This was due to a composition of moderately graded recycled ballast that interlocked within the granular assembly much better than the very uniform fresh ballast recommended by the Australian Standards. The test results demonstrated the potential benefits of using a geocomposite in track, where it was able to reduce the vertical deformation of fresh ballast by $33 \%$ and recycled ballast by $9 \%$. It also reduced the lateral deformation of fresh ballast by about $49 \%$ and recycled ballast by $11 \%$. The apertures of the geocomposite offered a strong mechanical interlock with the ballast, forming a highly frictional interface. The geocomposite has proven to be effective in providing the key functions of reinforcement, and filtration and separation, thereby reducing the vertical and lateral deformations. The preliminary results of the Singleton study showed that geogrids could decrease the vertical strains of the ballast, with the obvious benefits of reducing the rate of deterioration of track geometry and decreasing the cost of maintenance. The effectiveness of this reinforcement increased as the subgrade decreased in stiffness. Transient strains of the ballast layer also decreased when geosynthetics were used. The strains that accumulated in the geogrids were influenced by the placement of the ballast and deformation of the subgrade, while the induced transient strains were mainly affected by the stiffness of the geogrids. The findings of these field studies allows for a better assessment of the ability of geosynthetic reinforcement to mitigate degradation caused by cyclic and impact wheel loads, as well as more economical and effective design and maintenance of ballasted rail tracks.

\section{ACKNOWLEDGEMENTS}

The authors are grateful to the CRC for Rail Innovation for the funding of this research. The authors express their sincere thanks to Australian Research Council, RailCorp (Sydney), ARTC and Queensland Rail National for their continuous support. The authors would like to thank Mr. Alan Grant, Cameron Neilson and Ian Bridge of the University of Wollongong for their technical assistance throughout the period of this study. The on-site assistance provided by Mr. David Williams of ARTC is also appreciated.

\section{REFERENCES}

Ashmawy, A. K. and Bourdeau, P. L. (1995). "Geosynthetic-reinforced soils under repeated loading: a review and comparative design study." Geosynthetics International, 2(4): 643-678. 
Brown, S. F., Kwan, J. and Thom, N. H. (2007). "Identifying the key parameters that influence geogrid reinforcement of railway ballast." Geotextiles and Geomembranes, 25(6): 326-335.

Indraratna, B., Hussaini, S. K. and Vinod J. S. (2011a). "On the shear behaviour of ballast-geosynthetic interfaces.” Geotechnical Testing Journal, ASTM 35(2): 18.

Indraratna, B., and Salim, W. (2003). "Deformation and degradation mechanics of recycled ballast stabilised with geosynthetics” Soils Found., 43(4): 35-46.

Indraratna, B., Lackenby, J., and Christie, D. (2005). "Effect of confining pressure on the degradation of ballast under cyclic loading." Geotechnique, UK, 55(4): 325328.

Indraratna, B., Shahin, M. A., and Salim, W. (2007). "Stabilising granular media and formation soil using geosynthetics with special reference to Railway engineering.” Ground Improvement, 11(1): 27-44.

Indraratna, B., Nimbalkar, S., Christie, D., Rujikiatkamjorn, C., and Vinod, J. S. (2010) "Field assessment of the performance of a ballasted rail track with and without geosynthetics.” J. Geotech. Geoenviron. Eng., ASCE, 136(7): 907-917.

Indraratna, B., Salim, W., and Rujikiatkamjorn, C. (2011b) Advanced Rail Geotechnology - Ballasted Track: CRC Press/Balkema.

Jenkins, H. M., Stephenson, J. E., Clayton, G. A., Morland, J. W., and Lyon, D. (1974). "The effect of track and vehicle parameters on wheel/rail vertical dynamic forces.” Railway Engineering Journal, 3: 2-16.

Lackenby, J., Indraratna, B., McDowell, G., and Christie, D. (2007). "Effect of confining pressure on ballast degradation and deformation under cyclic triaxial loading." Geotechnique, 57(6): 527-536.

Marsal, R. J. (1973). Mechanical properties of rock fill. In: Hirschfield R. C. and Pools, S. J. (eds) Embankment Dam Engineering: Casagrande Volume, Wiley, New York, 109-200.

Nimbalkar, S., Indraratna, B., Dash, S. K., and Christie, D. (2012). "Improved performance of railway ballast under impact loads using shock mats." $J$. Geotech. Geoenviron. Eng., ASCE, 138(3): 281-294.

Raymond, G. P. (2002). "Reinforced ballast behaviour subjected to repeated load." Geotext. Geomembr. 20(1): 39-61.

RCA Australia (2008). "Geotechnical Investigation Report for Minimbah Bank Third Track.” RCA Australia, Newcastle, Australia.

Rowe P. K. and Jones C. P. (2000). "Geosynthetics: innovative materials and rational design.” In: Proceedings, GEOENG 2000, Melbourne, Australia, 1124-1156.

Selig, E. T., and Waters, J. M. (1994). Track Geotechnology and Substructure Management, Thomas Telford, London. Reprint 2007.

Shin E. C., Kim D. H. and Das B. M. (2002). "Geogrid-reinforced railroad bed settlement due to cyclic load.” Geotechnical and Geological Engineering, 20(3): 261-271.

Standards Australia. (1996). Aggregates and rock for engineering purposes, Part 7: Railway ballast AS 2758.7-1996. Sydney, NSW, Australia. 